\title{
Nepenthes mirabilis (Lour.) Druce Planlet at a Various Levels of Murashige \& Skoog Medium Density In Vitro
}

\author{
Nadia Fakhriyati Arfa, Endang Nurcahyani, Zulkifli, Tundjung Tripeni Handayani \\ Jurusan Biologi FMIPA Universitas Lampung \\ Jalan Soemantri Brodjonegoro No.1. Bandar lampung, Indonesia, 35145 \\ *Email: endang nurcahyani@yahoo.com
}

\begin{abstract}
This study aims to determine the variation of the stomata index of the Kantong Semar (Nepenthes mirabilis) planlet at a various medium density of the Murashige and Skoog. This study used a Completely Randomized Design using one factor (medium density of the Murashige and Skoog). We used 5 levels of medium density, i.e.: 1/16 MS, 1/8 MS, 1/4 MS, $1 / 2$ MS, and MS. Homogeneity test used Levene's test of $5 \%$ significance level, then analysis of variance is carried out at 5\% significance level and followed by Tukey test at $5 \%$ significance level. The results showed that the lower the level of Murashige and Skoog medium density on the Nepenthes mirabilis plantlet, the stomata index also increased.
\end{abstract}

Keyword: stomata index, in vitro, Murashige and Skoog, Nepenthes mirabilis

\section{PENDAHULUAN}

Nepenthes atau kantong semar merupakan tumbuhan karnivora yang di setiap ujung daunnya memiliki kantong yang unik. Kantong yang unik ini dapat menjebak serangga atau hewan kecil lainnya, karena di dalam kantongnya terdapat nectar glands (kelenjar madu) yang dapat memikat serangga khususnya yang menyukai rasa manis. Nepenthes memiliki dinding permukaan kantong licin, sehingga ketika mendekati kantong serangga akhirnya terpeleset dan terperangkap di dalam kantong (Handoyo dan Sitanggang, 2006).

Potensi sebagai tanaman hias dan manfaat lain yang dimiliki oleh Nepenthes menjadikannya tanaman yang banyak dicari. Akibatnya, keberadaannya di alam menjadi terancam karena banyaknya ancaman berupa kebakaran hutan dan lahan, konversi lahan dan pelebaran jalan (Hernawati \& Akhriadi, 2006). Oleh karena itu, Nepenthes mirabilis termasuk dalam kategori Appendix-2. Tanaman-tanaman yang masuk dalam Appendix-2 merupakan tanaman yang terancam punah namun populasinya lebih banyak berada di alam (Anonymous, 1999).

Keberhasilan dalam penggunaan metode kultur jaringan sangat bergantung pada medium yang digunakan. Umumnya medium kultur jaringan tersusun atas komposisi hara makro, hara mikro, vitamin, gula, asam amino dan sumber organik, persenyawaan kompleks alamiah, buffer, zat pengatur tumbuh (terutama auksin dan sitokinin), dan bahan pemadat (Alitalia, 2008). Keberhasilan kultur jaringan juga dipengaruhi oleh keasaman medium. Keasaman medium ditetapkan antara 5,6-5,8 karena $\mathrm{pH}$ yang tinggi menyebabkan unsur-unsur seperti besi, seng, mangan, tembaga, dan boron mengalami presipitasi sebagai hidroksida sehingga tidak tersedia bagi jaringan yang dikulturkan, sedangkan pada $\mathrm{pH}$ rendah, unsur-unsur seperti kalsium, belerang, dan fosfor menjadi tidak tersedia (Zulkarnain,2009). 
Medium tanam kultur jaringan yang sering digunakan adalah medium Murashige \& Skoog (MS). Medium MS dapat diaplikasikan pada sejumlah besar spesies (Rosmaina, 2011) karena medium MS memiliki kandungan garam-garam yang lebih tinggi dari medium lainnya dan senyawa nitrat yang juga tinggi (Zulkarnain, 2009).

Stomata juga berperan penting bagi kehidupan tumbuhan, karena pori stomata merupakan tempat terjadinya pertukaran gas dan air antara atmosfer dengan sistem ruang antar sel yang berada pada jaringan mesofil di bawah epidermis (Mulyani, 2006). Stomata terdiri atas sel penjaga dan sel penutup yang dikelilingi oleh beberapa sel tetangga. Stomata umumnya terdapat pada permukaan bawah daun, tetapi ada beberapa spesies tumbuhan dengan stomata pada permukaan atas dan bawah daun. Bentuk atau tipe stomata dibedakan atas 4 macam, yaitu anomositik, anisositik, parasitik, dan diasitik (Rompas, 2011).

Setiap sel tumbuhan mempunyai struktur sel epidermis yang berbeda. Perbedaan struktur sel epidermis yang dimaksud dapat berupa bentuk dan susunan sel epidermis, letak atau kedudukan stomata terhadap sel tetangga, arah membukanya stomata, bentuk stomata, jumlah sel epidermis dan stomata, serta jarak antara stomata dan panjang sel epidermis dan stomata. Ada tidaknya pengaruh indeks stomata pada daun planlet Nepenthes mirabilis masih belum banyak diketahui. Kajian mengenai indeks stomata pada tanaman kantong semar juga masih terbatas. Oleh sebab itu, penelitian ini perlu dilakukan untuk memberikan informasi ilmiah tentang stomata pada planlet kantong semar khususnya Nepenthes mirabilis.
Penelitian ini bertujuan untuk mengetahui karakter spesifik planlet Nepenthes mirabilis pada berbagai tingkat kepadatan medium Murashige \& Skoog khususnya pada indeks stomata planlet tersebut.

\section{METODE PENELITIAN}

Bahan- bahan yang digunakan pada penelitian ini adalah planlet Nepenthes mirabilis, alkohol $70 \%$, aquades, Kalium Hidroksida $(\mathrm{KOH})$, Asam Chlorida $(\mathrm{HCl})$, serta bahan kimia medium MS (Murashige \& Skoog) padat.

Penelitian ini dilakukan dengan pola dasar Rancangan Acak Lengkap (RAL) menggunakan satu faktor yaitu tingkat kepadatan medium MS (Murashige \& Skoog), terdiri atas 5 taraf yaitu: 1/16 MS, 1/8 MS, 1/4 MS, 1/2 MS, dan MS.

Pembuatan preparat stomata menggunakan metode Ruzin (1999). Daun planlet dibuat potongan-potongan segi empat dengan sisi $\pm 5 \mathrm{~mm}$ dan dimasukkan ke dalam tabung berisi larutan cloralhidrat dalam air (5:1). Tiap sel epidermis (E) ditandai dengan (x), tiap stoma (S) ditandai dengan (O). Setelah itu letakan pada gelas benda, preparat diamati pada 3 bagian daerah yang berlainan. Indeks stomata besarnya dihitung dengan rumus:

$$
\text { Indeks Stomata: } \frac{S}{E+S} \times 100 \%
$$

Data kuantitatif dari setiap parameter di uji homogenitas menggunakan uji Levene taraf nyata $5 \%$ kemudian dianalisis menggunakan Analisis ragam dilakukan pada taraf nyata 5\% dan apabila diperoleh hasil perbedaan nyata maka dilanjutkan dengan uji Turkey pada taraf nyata $5 \%$. 


\section{HASIL DAN PEMBAHASAN}

Hasil indeks stomata planlet Nepenthes mirabilis yang ditanam pada berbagai tingkat kepadatan medium Murashige \& Skoog menunjukkan bahwa Uji Levene pada taraf nyata $5 \%$ menunjukkan ragam kelima medium adalah homogen $(P>$ $0,05)$. Analisis ragam pada taraf nyata $5 \%$ juga menunjukkan bahwa kepadatan medium Murashige \& Skoog yang digunakan berpengaruh nyata terhadap indeks stomata Nepenthes mirabilis $(\mathrm{P}<$ $0,05)$. Uji lanjut dengan menggunakan Uji Tukey yang disajikan pada Tabel 1 .

Tabel 1 menunjukkan bahwa Uji Tukey menunjukkan kepadatan medium 1/16 MS tidak berbeda nyata terhadap 1/8 MS dan $1 / 4 \mathrm{MS}$, begitu juga dengan kepadatan medium 1/4 MS tidak berbeda nyata terhadap 1/2 MS dan MS. Namun kepadatan medium 1/16 MS dan 1/8 MS memberikan pengaruh nyata terhadap $1 / 2$ MS dan MS. Hal ini menunjukkan bahwa semakin rendah tingkat kepadatan medium Murashige \& Skoog pada planlet Nepenthes mirabilis maka semakin meningkat pula indeks stomatanya. Perbandingan indeks stomata Nepenthes mirabilis disajikan dalam bentuk grafik pada Gambar 1.

Tabel 1. Uji Tukey indeks stomata planlet Nepenthes mirabilis dengan berbagai tingkat kepadatan medium MS

\begin{tabular}{lc}
\hline $\begin{array}{l}\text { Kepadatan } \\
\text { Medium MS }\end{array}$ & $\begin{array}{c}\text { Indeks Stomata (\%) } \\
\bar{Y} \pm \text { SE }\end{array}$ \\
\hline $1 / 16$ & $14,986 \pm 0,784^{\mathrm{a}}$ \\
$1 / 8$ & $10,580 \pm 1,645^{\mathrm{a}}$ \\
$1 / 4$ & $9,352 \pm 2,159^{\mathrm{ab}}$ \\
$1 / 2$ & $7,534 \pm 1,741^{\mathrm{b}}$ \\
1 & $3,805 \pm 0,637^{\mathrm{b}}$ \\
\hline Keterangan: & Angka yang diikuti oleh \\
& huruf yang sama tidak \\
& beda nyata pada taraf $5 \%$. \\
& BNJ $(0.05)=6,41$
\end{tabular}

Berdasarkan Gambar 1, hasil dari grafik indeks stomata planlet Nepenthes mirabilis (Lour.) Druce mengalami penurunan seiring dengan meningkatnya kepadatan medium MS. Karena itu, dari gambar terlihat bahwa medium yang optimum dalam indeks stomata planlet Nepenthes mirabilis yaitu pada medium 1/6 MS serta tidak berbeda nyata pada medium 1/8 MS. Terlihat pula bahwa semakin tinggi tingkat kepadatan medium MS, maka indeks stomata yang dihasilkan juga semakin rendah.

Stomata juga terdiri atas sel penjaga dan sel penutup yang dikelilingi oleh beberapa sel tetangga. Stomata umumnya terdapat pada permukaan bawah daun, tetapi ada beberapa spesies tumbuhan dengan stomata pada permukaan atas dan bawah daun. Bentuk atau tipe stomata dibedakan atas 4 macam, yaitu anomositik, anisositik, parasitik, dan diasitik (Rompas, 2011). Stomata pada permukaan bawah daun planlet Nepenthes mirabilis disajikan pada Gambar 2.

Berdasarkan Gambar 2. terlihat stomata daun planlet Nepenthes mirabilis berbentuk ginjal dan tergolong tipe anomositik seperti pada tumbuhan dikotil pada umumnya. Stomata ini teramati dalam posisi terbuka, serta terlihat porus atau celah yang terbuka.

Pada stomata terdapat sel penutup yang dikelilingi sel tetangga yang biasanya berkembang dari sel protoderm yang berdekatan dengan sel induk stomata, tetapi dapat juga berkembang dari sel induk stomata. Hal ini sesuai dengan pendapat Fahn (1991) bahwa pada tanaman dikotil, sel penjaganya berbentuk ginjal. Stomata daun Nepenthes mirabilis tergolong tipe anomositik. Tipe anomositik adalah tipe sel tetangga yang memiliki kesamaan bentuk dan ukuran dengan sel epidermis disekitarnya. 


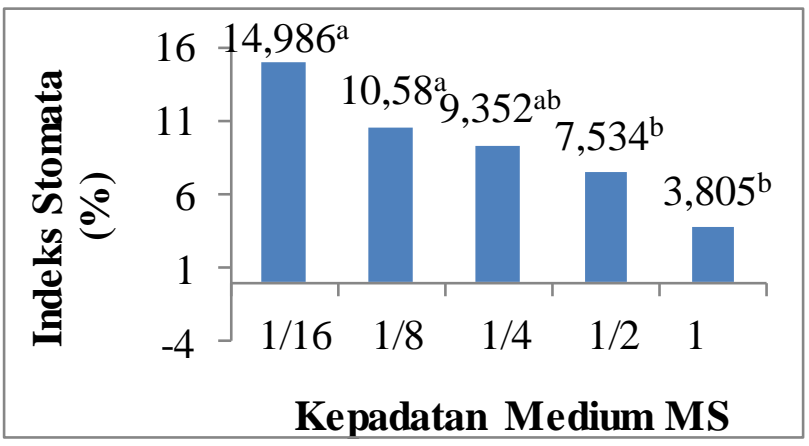

Gambar 1. Grafik indeks stomata planlet Nepenthes mirabilis dengan berbagai tingkat kepadatan medium MS

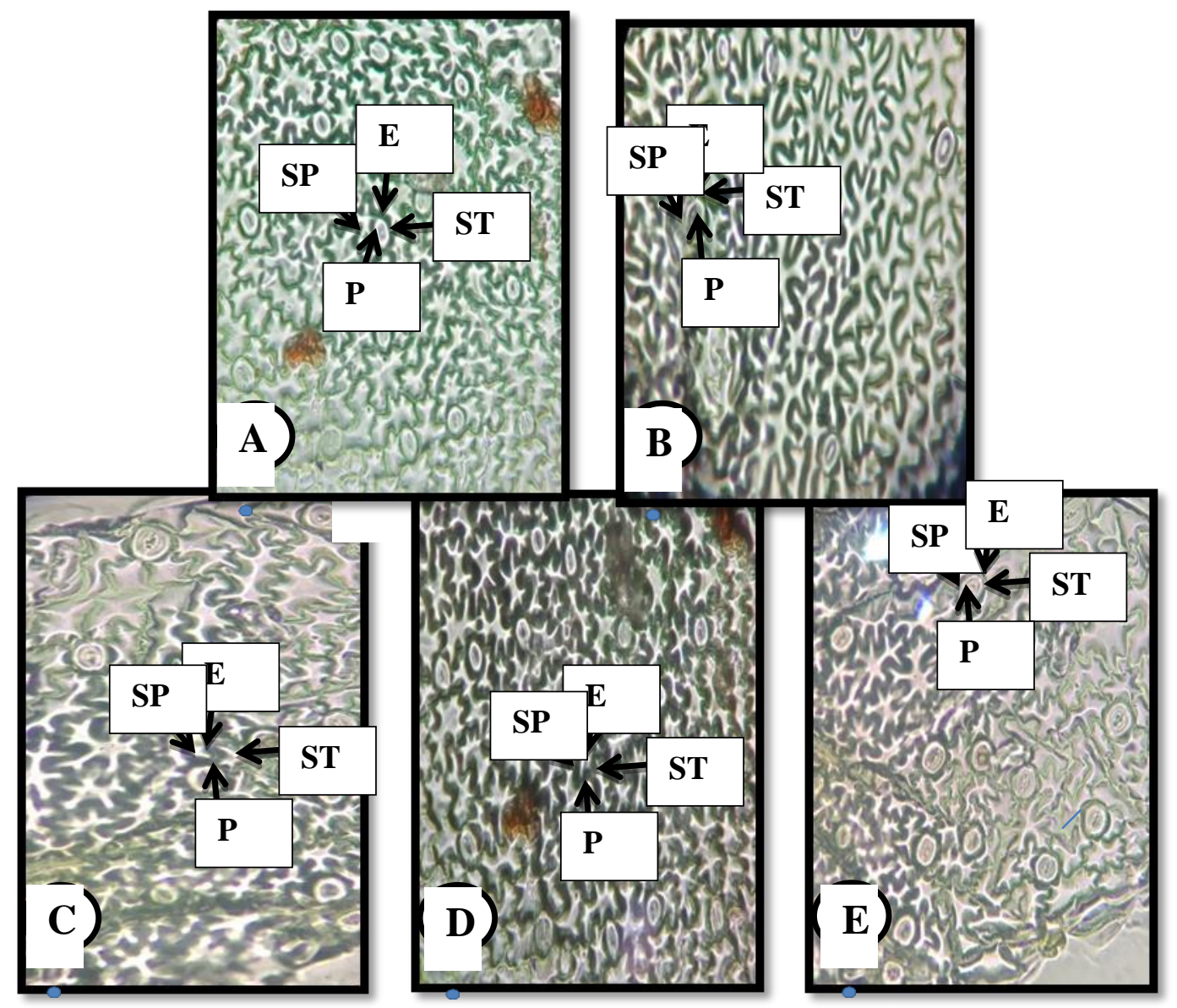

Gambar 2. Permukaan bawah daun planlet Nepenthes mirabilis, menunjukkan stomata daun (A) MS, (B) 1/2 MS, (C) 1/4 MS, (D) 1/8 MS, (E) 1/16 MS; E = epidermis, ST = sel tetangga, $\mathrm{P}=$ porus, $\mathrm{SP}=$ sel penutup.

\section{KESIMPULAN}

Perlakuan medium 1/16 MS memberikan pengaruh nyata paling baik pada stomata daun planlet Nepenthes mirabilis serta tidak berbeda nyata dengan medium 1/8 MS. Hal ini menunjukkan bahwa semakin rendah tingkat kepadatan medium Murashige \& Skoog pada planlet 
Nepenthes mirabilis maka semakin meningkat pula indeks stomatanya.

\section{DAFTAR PUSTAKA}

Alitalia, Y. (2008). Pengaruh Pemberian BAP dan NAA Terhadap Pertumbuhan dan Perkembangan Tunas Mikro Kantong Semar (Nepenthes mirabilis) Secara in vitro. (Skripsi). Bogor: Program Studi Hortikultura Fakultas pertanian. Institut Pertanian Bogor.

Anonymous. (1999). Convention on International Trade in Endangered Species Of Wild Fauna And Flora. Seventeenth Meeting of The Plants Committee Geneva (Switzerland).

Fahn, A. (1991). Anatomi Tumbuhan (Edisi ke-3). Yogyakarta: Universitas Gajah Mada.

Handoyo F. dan Sitanggang M. (2006). Petunjuk Praktis Perawatan Nepenthes. Depok: Agromedia.

Nepenthes Team, BP Conservation Programme. Padang.
Hernawati dan Akhriadi P. (2006). A Field Guide to The Nepenthes of Sumatra. PILI-NGO Movement Mulyani, Sri. (2006). Anatomi Tumbuhan. Yogyakarta: Kanisius.

Rompas, Yulanda. (2011). Struktur Sel Epidermis dan Stomata Daun Beberapa Tumbuhan Suku Orchidaceae. Jurnal Biologos, 1(1), 1-7.

Rosmaina. (2011). Laju Multiplikasi Nenas (Ananas comosus L) pada Media Dasar MS Hasil Perlakuan BA dan NAA secara In Vitro. Jurnal Agroteknologi, 1(1), 32-37.

Ruzin, S.E. (1999). Plant Microtecnique and Microscopy. New York: Oxford University Press.

Zulkarnain. (2009). Kultur Jaringan Tanaman, Solusi Perbanyakan Tanaman Budi Daya. Jakarta: PT. Bumi Aksara 